\title{
PROTOTYPE THEORY IN THE JUDICIAL PRACTICE OF THE COURT OF JUSTICE OF THE EUROPEAN UNION. A CASE STUDY ${ }^{1}$
}

\author{
MATEUSZ ZEIFERT, PhD \\ University of Silesia in Katowice, Poland \\ ul. Bankowa 11B, 40-007 Katowice \\ mateusz.zeifert@us.edu.pl
}

ORCID: https://orcid.org/ 0000-0003-3266-3397

\begin{abstract}
Prototype theory is a semantic theory according to which the membership of conceptual categories is based not on a list of criterial features, but rather on the similarity to the most representative member of the category. Consequently, conceptual categories may lack classical definitions and rigid boundaries. This article supports the claims, already made by other scholars working in the field, that prototype theory may greatly augment our understanding of legal (i.e. statutory, judicial) interpretation. Legal provisions are traditionally written as classical definitions, but they are rarely applied that

\footnotetext{
${ }^{1}$ The article is a part of a research project "The meaning of statutory language in light of selected theories from cognitive linguistics", financed by National Science Centre, Poland (2018/31/D/HS5/03922).
} 
way. Statutory concepts tend to be interpreted with a great deal of flexibility, using a wide array of extra-textual factors. This is especially true for the case law of the Court of Justice of the European Union, which has to deal with the challenges of the multilingual, supranational law of the European Union.

Key words: judicial interpretation; legal semantics; prototype theory; cognitive linguistics; EU legislation.

\section{TEORIA PROTOTYPU W PRAKTYCE ORZECZNICZNEJ TRYBUNALU SPRAWIEDLIWOŚCI UNII EUROPEJSKIEJ - STUDIUM PRZYPADKU}

Streszczenie: Teoria prototypu jest teorią semantyczną, zgodnie z którą przynależność do kategorii pojęciowych nie opiera się na zestawie określonych cech, lecz na podobieństwie do najbardziej reprezentatywnego egzemplarza danej kategorii. W związku z tym kategorie pojęciowe mogą nie poddawać się klasycznemu definiowaniu, a ich granice bywają rozmyte. Artykuł ten wspiera twierdzenia innych autorów, że teoria prototypów może znacząco pogłębić nasze rozumienie interpretacji prawniczej. Przepisy prawne są tradycyjnie formułowane jak klasyczne definicje, jednak rzadko są stosowane $\mathrm{w}$ ten sposób. Pojęcia ustawowe są często interpretowane z dużą elastycznością, przy wykorzystaniu szerokiej palety czynników pozatekstowych. Jest to szczególnie aktualne w przypadku orzecznictwa Trybunału Sprawiedliwości Unii Europejskiej, który stoi przed wyzwaniem stosowania wielojęzycznego, ponadnarodowego prawa Unii Europejskiej.

Slowa kluczowe: interpretacja prawa; semantyka języka prawnego; teoria prototypu; językoznawstwo kognitywne; prawo Unii Europejskiej.

\section{Introduction}

Legal theory has always been interested in the achievements of philosophy of language, formal logic, linguistics and other languageoriented disciplines. This is because language is the most common means of expressing legal rules: "[t]he law is a profession of words" (Mellinkoff 2004: vii). Perhaps a more scholarly proposition would be that "law is not a discipline of words, but of concepts" (Bajčić 2017: 7), because when it comes down to it, concepts - not words - are the "crystallisations of legal rules" (Mattila 2006: 137). Bearing that in 
mind, in this article I advocate the relevance of a semantic theory named prototype theory as a way of understanding the practice of legal (i.e. statutory, judicial, juristic) interpretation. This is not a genuinely novel idea. Similar claims have been made by others in the fields of legal theory and legal linguistics (see, for example, Winter 2001; Solan 2010; Bajčić 2017). I offer some additional support for such claims in the form of a detailed analysis of the case law of the Court of Justice of the European Union. I also argue that prototype theory obtains particular significance in the context of the legal system of the European Union, due to its institutional, political and linguistic characteristics.

\section{Prototype theory - an overview}

Prototype theory is a theory of categorisation originating from the work of American psychologist, Eleanor Rosch. It is based on psycholinguistic experiments conducted in the 1970s. It goes directly against what is known as the classical approach to human categorisation. According to that approach, which can be traced back to Aristotle, conceptual categories are defined by sets of features that are both necessary and sufficient. An object is recognised as a member of a category if it exhibits all the relevant features. It follows that (1) all members of a category are equal, (2) membership of a category is an all-or-nothing affair, and therefore (3) categories have rigid boundaries. Classical theory prevailed for centuries in numerous disciplines, including philosophy, psychology, anthropology, linguistics and - most notably for our purposes - law. As Lawrence Solan puts it: "[s]tatutes are generally written as classical definitions, which in turn are familiar to us as rules that tell us the conditions that are necessary and sufficient for us to use a word appropriately" (Solan 2010: 18).

Rosch's research proved that the actual psychological mechanisms of categorisation do not comply with the classical approach, at least with reference to certain types of conceptual categories, including: colours and shapes, natural-kind names (i.e. bird, fruit), artefacts names (i.e. furniture, vehicle, weapon). Instead of being defined by a set of necessary and sufficient features, these categories were found to be organised around the best, or the most representative example - called the prototype. The membership of a category is 
established on the basis of similarity to the prototype. It results in an internal structure: "categories are composed of a 'core meaning' which consists of the 'clearest cases' (best examples) of the category, 'surrounded' by other category members of decreasing similarity to that core meaning" (Rosch 1973: 112). Extensive research by Rosch and others has proved that prototypes have psychological reality, i.e. they are involved in category processing, including association, speed of reaction, recognition, probability judgments, drawing inferences, learning, and memorising (Rosch 1973, 1978, 2011).

It should be stressed at this point that, contrary to a popular misreading, the notion of prototype should not be understood as referring to any particular entity, especially to a specific member of a category. Rather, it may refer to an abstract, idealised member of a category, a cluster of attributes providing the highest cue validity, or statistical functions over attributes: "To speak of a prototype at all is simply a convenient grammatical fiction; what is really referred to are judgments of degree of prototypicality" (Rosch 1975: 200). Rosch herself claims that there are no less than fourteen different types of prototypes that are appropriate for different types of conceptual categories (Rosch 2011: 101-103).

Although prototype theory originated in the field of experimental psychology, it has been quickly taken up by linguists from the emerging movement labelled cognitive linguistics, most notably by: George Lakoff, Charles Fillmore and Ronald Langacker. It offered an alternative for "checklist theories of meaning" (Fillmore 1975), i.e. formal semantics based on componential analysis, employed in the transformative-generative grammar. Today, prototype theory is considered one of the cornerstones of cognitive linguistics, and has been utilised in various domains of linguistic research, including lexical semantics, syntactic theory, morphology, and phonology. (see: Lakoff 1987; Langacker 2008; Taylor 2003). For convenience, it is often referred to as prototype theory. As a matter of fact, however, it is not a single theory, but rather a cluster of theories that share certain general characteristics (sometimes referred to as prototypical effects). According to Dirk Geerearts, these common characteristics boil down to the following four features (Geerearts 2016: 6-8):

(1) Prototypical categories cannot be defined by means of a single set of necessary and sufficient features. Take a classic example 
of a category FRUIT. ${ }^{2}$ Normally we expect fruits to be sweet, to have a certain size and shape, and to be eaten as a dessert. ${ }^{3}$ However, there are obviously fruits that are not sweet (i.e. grapefruit, avocado), that are extraordinarily large (i.e. watermelon, coconut), and that are used for other culinary purposes (i.e. cranberry, avocado, lime). This lack of common features makes it impossible to formulate a rigid, classical definition of the concept of fruit, as such definitions are based on single sets of sufficient and necessary features.

(2) The structure of prototypical categories takes the form of a radial set of clustered and overlapping senses. This characteristic is attributed to Ludwig Wittgenstein and is called family resemblance. It means that, instead of a set of common features, we can observe "a complicated network of similarities overlapping and criss-crossing: sometimes overall similarities, sometimes similarities of detail" (Wittgenstein 1953: 32). Apples and pears have a similar shape and size, which they share with peaches and apricots. The latter two, however, have also a large stone in them that makes them similar to plums, mangos and avocados. All these fruits grow on trees, just like cherries. Cherries, however, are much smaller in size, which makes them similar to grapes, blueberries, gooseberries and raspberries, etc.

(3) Prototypical categories exhibit degrees of category membership. This feature is also known as typicality or goodness-of-example. It means that not every member of a category is equally representative - some members are better examples than others, because they exhibit more relevant features of the category. This is how the core-periphery distinction is formed. Apples, pears, peaches and oranges are prototypical examples of fruits and they constitute the "core" of the category. Watermelons, tomatoes and avocados are less prototypical, because they lack some of the typical features of fruits (i.e. watermelons have an enormous size and grow on the ground, tomatoes and avocados are not sweet and are not served as a dessert, etc.). They constitute the "periphery" of the category. The phenomenon of typicality is

\footnotetext{
${ }^{2}$ Note that the ordinary or folk meaning of fruit is concerned here, not a botanical definition.

${ }^{3}$ These expectations are obviously culture-dependant (as opposed to universal), which is explicitly admitted in the prototype theory.
} 
encoded in natural languages in the form of so-called hedge words (typical, technically, virtually, strictly speaking, sort of, par excellence, etc.) It explains why we can say "Tomatoes are technically a fruit", while the sentence "Apples are technically a fruit" sounds peculiar (Lakoff 1973).

(4) Prototypical categories are blurred at the edges, which means that they do not have rigid boundaries. This links with the previous characteristics in that the degree of membership of a category may diminish to the point where it is no longer clear whether an object is still a member of the category. For instance: tomatoes, pumpkins, coconuts, olives and avocados are borderline fruits (Rosch 1975: 229-230). The non-rigidity of lexical categories poses serious problems for formal semantics, but not so much for everyday, practical purposes. From this perspective it should be rather considered a virtue (Wittgenstein 1953: 33).

There is also one very important meta-theoretical commitment shared by prototype theorists and cognitive linguists in general. It is the assumption that linguistic knowledge cannot be precisely separated from a background of general knowledge about the world. In other words, there is no strict border between linguistic meaning and other areas of conceptual information, and consequently between semantics and pragmatics. This idea has been developed by numerous scholars and under various theoretical propositions, including the concepts of a semantic frame (Fillmore 1975) and the Idealized Cognitive Model (ICM) (Lakoff 1987). For the purposes of this article, however, the notion of encyclopaedic semantics will be used (Langacker 2008: 4647).

\section{The interpretation of EU law}

The prototype theory is relevant for legal practice, and consequently for legal theory, because the process of applying the law can be viewed as an act of categorisation. The core of judicial activity consists in classifying particular factual situations into relevant legal categories. As aptly put by the famous legal philosopher Herbert L.A. Hart:

"[T]he law must (...), refer to classes of person, and to classes of acts, things, and circumstances; and its successful operation over vast areas 
of social life depends on a widely diffused capacity to recognize particular acts, things, and circumstances as instances of the general classifications which the law makes" (Hart 1994: 124).

Although categorisation is a complex cognitive operation, in the absence of doubts the human mind is capable of performing it unconsciously. In legal theory, such instances are often called easy cases. However, whenever doubts arise, legal categorisation becomes a deliberate process known to lawyers as legal interpretation or legal construction. Lawrence Solan describes it in the following way: "Most disputes over the meanings of statutes are about the fit between events in the world and the words in the statute" (Solan 2010: 50). These are known as hard cases and are the bread and butter of the judiciary in every legal system. The legal system of the European Union (hereinafter: the EU) is no exception.

The EU courts, most notably the Court of Justice of the European Union (hereinafter: CJEU), are given the task of applying and consequently - interpreting EU law, including both primary law in the form of European treatises, as well as secondary law consisting of regulations, directives, decisions, recommendations and opinions. As documented by the CJEU case law, the interpretation of EU law does not essentially differ from the interpretation of national law and utilises traditional methods of interpretation, namely linguistic (or textual), systemic (or contextual) and teleological (or purposive) (Lenaerts and Gutiérrez-Fons 2013: 4; Pacho Aljanti 2018: 33). However, two characteristic features of EU law are frequently discerned in the literature: conceptual autonomy and multilingualism (Bajčić 2017: 79106). Conceptual autonomy leads to the semantic independence of EU law. The legal concepts encapsulated in EU legislation are not the same as national legal concepts, even if denoted by the same terms (Bajčić 2017: 80). The multilingualism of EU law is a major topic in legal linguistics (see, for example, Šarčević 2013; Bajčić 2017). Put very simply, it means that every piece of European legislation has 24 language versions, with each version being equally authentic, "meaning that 24 different terms must refer to the same European concept" (Bajčić 2017: 165). Such a policy creates numerous practical problems. One of them is the existence of inevitable discrepancies between different language versions. In the CJEU's interpretive practice, this has resulted in a diminished role of textual methods and a reliance on 
extralinguistic methods, including the teleological (i.e. purposive) approach, which the Court is famous for (Fenelly 1996: 664).

These two features of EU law, namely conceptual autonomy and multilingualism, offer a unique theoretical perspective. As rightly noted in the literature: [W]ithin a multilingual legal environment such as the EU, the (...) problems of understanding the law are multiplied" (Bajčić 2017: 137). If we view, as Solan and many other theorists do, the application of law as an art of matching a legal provision with reality, then the application of EU law may be perceived as an art of matching two dozen legal provisions with more than two dozen different realities. As a result, CJEU case law provides fertile soil for semantic analyses.

\section{The concept of judicial authority}

The case study in this article is based on a series of CJEU judgments concerning the European Arrest Warrant (hereinafter: EAW). The EAW is an instrument of judicial co-operation in the area of criminal justice. It was introduced by the Council Framework Decision of 13 June 2002 on the European arrest warrant and the surrender procedures between Member States (2002/584/JHA). It is considered to be the main EU legislative reaction to the events of 9/11 (Klimek 2015: 365). Amongst the Member States, the Framework Decision has replaced the traditional multilateral system of extradition based on political decisions with a system based on the principle of the mutual recognition of judicial decisions. On the one hand, the system is relatively simple, fast and effective. It has been praised as being possibly "the most successful mutual recognition instrument ever" (Klimek 2015: 1). On the other hand, it has the potential to violate important legal values, including the accused or the convicted person's fundamental rights (van der Mei 2017: 883). It does not come as a surprise, then, that CJEU case law concerning various aspects of the EAW system is very rich and not without controversy. For the purposes of this article, only one of these aspects will be discussed, namely the concept of judicial authority.

According to the legal definition provided in the Framework Decision: 
The European arrest warrant is a judicial decision issued by a Member State with a view to the arrest and surrender by another Member State of a requested person, for the purposes of conducting a criminal prosecution or executing a custodial sentence or detention order. ${ }^{4}$

The body responsible for issuing (as well as executing) an EAW is denoted as judicial authority:

The issuing judicial authority shall be the judicial authority of the issuing Member State which is competent to issue a European arrest warrant by virtue of the law of that State. ${ }^{5}$

Judicial authority is a pivotal term, given the high stakes involved in issuing an EAW. However, it is not defined in the act. Prima facie, the term should not pose interpretive problems. English legal dictionaries define the adjective judicial quite clearly as "referring to a judge, court or the court system" " or "relating to the courts or belonging to the office of a judge." 7 Therefore, it seems that judicial authority should be interpreted as covering only courts as institutions and individual judges. ${ }^{8}$ However, there are 22 other authentic language versions of the term. ${ }^{9}$ Many of them also refer directly to judges or courts (i.e. the Polish version: organ sądowy and the Slovakian version: súdny orgán). However, some versions may be construed more broadly, as covering also institutions other than courts or judges (i.e. the Swedish version: rättsliga myndigheten or the German version: Justizbehörde). These linguistic differences constitute the first layer of semantic discrepancies. It may be worth noting that the CJEU occasionally acknowledges such differences and conducts a comparative linguistic analysis as part of the interpretive process (Pacho Aljanti 2018; Paluszek 2019). However, this was not employed in cases concerning the term in question. It follows that it is not linguistic differences that pose the real interpretive problems.

\footnotetext{
${ }^{4}$ Article 1(1) (2002/584/JHA).

${ }^{5}$ Article 6(1) (2002/584/JHA).

6 The People's Law Dictionary by Gerald and Kathleen Hill. URL: https://dictionary.law.com/Default.aspx?selected $=1062$

7 West's Encyclopedia of American Law, edition 2. Copyright 2008 The Gale Group, Inc. URL: https://legal-dictionary.thefreedictionary.com/judicial

${ }^{8}$ Note, however, that the term court has not been given a rigid definition by the Court (see: Bajčić 2017: 145).

${ }^{9}$ The Gaelic version is currently unavailable. For reference, see: table 1.
} 
Mateusz Zeifert: Prototype Theory....

Table 1. The terms for judicial authority in different EU language versions:

\begin{tabular}{|c|c|}
\hline Language version & Term used \\
\hline ENG & Judicial authority \\
\hline $\mathrm{BG}$ & съдебен орган \\
\hline ES & autoridad judicial \\
\hline $\mathrm{SC}$ & justiční orgán \\
\hline $\mathrm{DA}$ & judicielle myndighed \\
\hline $\mathrm{DE}$ & Justizbehörde \\
\hline ET & õigusasutus \\
\hline EL & 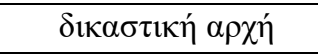 \\
\hline FR & autorité judiciaire \\
\hline GA & - \\
\hline HR & Pravosudno tijelo \\
\hline IT & autorità giudiziaria \\
\hline LV & tiesu iestāde \\
\hline LT & teisminè institucija \\
\hline $\mathrm{HU}$ & igazságügyi hatóság \\
\hline MT & L-awtorità gudizzjarja \\
\hline NL & rechterlijke autoriteit \\
\hline PL & Organ sądowy \\
\hline PT & autoridade judiciária \\
\hline RO & Autoritatea judiciară \\
\hline SK & súdny orgán \\
\hline SL & pravosodni organ \\
\hline FI & oikeusviranomainen \\
\hline SV & rättsliga myndigheten \\
\hline
\end{tabular}

The second and, judging from the role it plays in the CJEU's considerations, much more essential layer of semantic discrepancies is constituted by differences between the legal systems of the Member States. Although the general principles of the rule of law and the separation of powers are shared among all Member States, the specifics of the legal systems involved vary significantly. This includes the shape of criminal justice systems: their structure, hierarchy, internal institutional relations, external relations with other branches of government, number, types and character of institutions, procedural issues, etc. For instance, in some Member States, the pre-trial part of criminal proceedings is the domain of public prosecutors, while in 
others it is run by examining magistrates or investigative judges. In some Member States, prosecutors' offices are part of the judiciary, while in others they are subordinate to the executive. According to Article 6(1) of the Framework Decision, each Member State is entitled to assign the judicial authority responsible for issuing an EAW accordingly to its national law. Due to organisational, practical, political, historical or other reasons, many states have given the authority to issue an EAW to non-court bodies or offices, such as public prosecutors' offices, police services or ministries of justice. ${ }^{10} \mathrm{Of}$ course, these authorities also vary from state to state in their institutional position, internal organisation, procedural issues, etc. As a result, it is not always clear, especially for the prosecuted person, whether an institution assigned by a particular Member State should count as a judicial authority. Hence in the last couple of years, ${ }^{11}$ there have been numerous requests for preliminary rulings from CJEU whose real concern was the meaning and scope of the term judicial authority or, in other words, the contents of the concept of judicial authority.

Table 2. Institutions and persons capable of issuing EAWs in legal systems of different Member States (based on Questionnaire on the CJEU's judgments in relation to the independence of issuing judicial authorities and effective judicial protection by Eurojust \& European Judicial Agency).

\begin{tabular}{|l|l|}
\hline $\begin{array}{c}\text { Member } \\
\text { State }\end{array}$ & \multicolumn{1}{c|}{ Issuing authority } \\
\hline AT & $\begin{array}{l}\text { Prosecutor (but EAW becomes valid only if it is authorized by } \\
\text { a judge) }\end{array}$ \\
\hline BE & $\begin{array}{l}\text { Investigative judge or prosecutor (following an arrest warrant } \\
\text { issued by a court in the trial phase, or for the purpose of } \\
\text { prosecution of minors, or for the purpose of the execution of } \\
\text { sentences) }\end{array}$ \\
\hline BG & Public prosecutor or court \\
\hline CY & District court judge \\
\hline CZ & Court \\
\hline
\end{tabular}

${ }^{10}$ See: table 2 for reference. Note, however, that some Member States have already adjusted their legislation to match recent CJEU case law and thus the contents of the table may diverge from the analyses presented in the article.

11 The recent increase in the numbers of preliminary rulings on EAW-related issues has to do with a procedural change that entered into force in 2014. Since then, the Court's preliminary rulings on criminal matters are no longer subject to prior acceptance by the Member States (see: van der Mei 2017: 882-883). 
Mateusz Zeifert: Prototype Theory....

\begin{tabular}{|l|l|}
\hline DK & Court \\
\hline DE & Court \\
\hline EE & Prosecutor's office \\
\hline EL & Public Prosecutor of the Court of Appeals \\
\hline ES & Investigative judge or court \\
\hline FI & Public prosecutor \\
\hline FR & Public prosecutor's office \\
\hline HR & Public prosecutor \\
\hline HU & Investigative judge or court \\
\hline IE & The High Court \\
\hline IT & $\begin{array}{l}\text { Investigative judge or court or public prosecutor (for the } \\
\text { purpose of the execution of sentences) }\end{array}$ \\
\hline LT & Prosecutor General's Office or County Court \\
\hline LU & $\begin{array}{l}\text { Investigative judge or Prosecutor General (for the purpose of } \\
\text { the execution of sentences) }\end{array}$ \\
\hline LV & The Prosecutor General's Office \\
\hline MT & Court of Magistrates \\
\hline NL & Investigative judge \\
\hline PL & Circuit court \\
\hline PT & Public prosecutor or judge \\
\hline RO & Court \\
\hline SE & Public prosecutor \\
\hline SI & Investigative judge \\
\hline SK & Court \\
\hline UK & Judge \\
\hline NO & Regional public prosecutor \\
\hline
\end{tabular}




\section{The case study}

The first judgment in the series was case C-452/16 PPU (Poltorak). ${ }^{12}$ The facts of the case are as follows: Mr Poltorak, a Polish national, was given a custodial sentence by a District Court in Sweden. The EAW with a view to executing that sentence in Sweden was issued by the Swedish police board, in accordance with the national law. The executing authority requested a preliminary ruling from the CJEU regarding its doubts as to whether the police board can be counted as the issuing judicial authority for the purposes of executing a custodial sentence. The Court acknowledged that the term judicial authority is not defined in the act, and that it requires "an autonomous and uniform interpretation which (...) must take into account the terms of that provision, its context and the objective of the Framework." Next, the Court stated that "the words 'judicial authority', contained in that provision, are not limited to designating only the judges or courts of a Member State, but may extend, more broadly, to the authorities required to participate in administering justice in the legal system concerned." However, referring to the principle of the separation of powers, the Court drew a line between authorities administering justice (which can be considered as judicial) and the administrative or police authorities, which are within the province of the executive. Consequently, it ruled that the term judicial authority cannot be interpreted as covering the police services of a Member State.

On the same day, a judgment was passed in the case C-477/16 PPU (Kovalkovas). ${ }^{13}$ The request for a preliminary ruling was made in connection with the execution of an EAW issued by the Ministry of Justice of the Republic of Lithuania with a view to executing a custodial sentence. The argumentation of the Court was nearly identical to the one provided in the previous ruling. It was based on the distinction between judicial and administrative authorities, with the Ministry of Justice obviously falling within the scope of the latter.

These cases make the first series of CJEU judgments concerning the concept of judicial authority. ${ }^{14}$ On the one hand, the

\footnotetext{
12 Judgment of 10 November 2016.

13 Judgment of 10 November 2016.

14 The third judgment of that day is C-453/16 PPU (Özçelik) which deals with a different - though largely interconnected - issue, namely the concept of judicial decisions.
} 
rulings confirmed that the concept should be construed as denoting not only judges or courts, but also other authorities participating in administering justice. Note that this is contrary to some language versions of Article 6(1) of the Framework Decision, which seem to refer exclusively to courts. On the other hand, it drew a line between judicial and administrative authorities, defining police services and ministries of justice as the latter. These considerations, however, have mostly a negative or exclusionary aspect - they tell us which authorities do not count as judicial authorities, yet they do not provide us with any substantial definition of the term in question.

The second series of judgments was passed in 2019 and comprises of three cases. In the joined cases C-508/18 and C-82/19 PPU, ${ }^{15}$ EAWs were issued by the offices of German public prosecutors for the purposes of criminal prosecution. Building on the previous case law, the Court initially recognised that public prosecutor's offices in Germany must be regarded as participating in the administration of criminal justice. As such they meet the institutional requirements put forward in C-452/16 PPU and C-477/16 PPU cases. Nevertheless, the Court questioned the independency of the issuing authorities from the executive. According to the information provided by the German government, public prosecutor's offices in Germany are part of a hierarchical structure that is connected with the minister for justice of a given Land. A minister for justice has the power to issue instructions to public prosecutors in specific cases. Although this power is exercised very rarely and in accordance with statutory law, and had not been exercised in the cases in question, the risk remains that a decision on issuing EAW may be influenced by the executive. For this reason, the CJEU ruled that the concept of judicial authority,

\footnotetext{
must be interpreted as not including public prosecutors' offices of a Member State which are exposed to the risk of being subject, directly or indirectly, to directions or instructions in a specific case from the executive, such as a Minister for Justice, in connection with the adoption of a decision to issue a European arrest warrant.
}

On the same day, a judgment was passed in case C-509/18 ${ }^{16}$ concerning an EAW issued by the Prosecutor General of Lithuania for the purposes of a criminal prosecution. The argumentation was almost

\footnotetext{
15 Judgment of 27 May 2019.

16 Judgment of 27 May 2019.
} 
identical to the one discussed above, except for the conclusion. The Court recognised that the Lithuanian prosecutor general, although institutionally independent from the judiciary, is also independent from the executive in the context of issuing an EAW. Consequently, it meets not only the institutional requirements discerned in the previous case law, ${ }^{17}$ but also the requirement regarding independence from the executive, which was not met by the German public prosecutors' offices.

This second series of judgments provided a refinement of the concept of judicial authority. A new definitional element was added, namely the requirement of independence from the executive. As we have seen, not all prosecutors' offices of the Member States meet this requirement.

The third and the most recent series of judgments was passed at the end of 2019. In case C-489/19 PPU $^{18}$ a request for a preliminary ruling was made in the context of the execution of an EAW issued by an Austrian public prosecutor's office for the purposes of conducting a criminal prosecution. The Court acknowledged that public prosecutors' offices in Austria are directly subordinate to the higher public prosecutors' offices and subject to their instructions, and that the latter are in turn subordinate to the Federal Minister of Justice. Therefore they do not meet the criterion of independence, just like their colleagues from Germany. However, an EAW issued by a prosecutor's office in Austria, in order for it to be transmitted, must be endorsed by a court, which checks the conditions necessary for the issue and the proportionality of the EAW. The endorsement decision is subject to appeal before courts. This complies with the demand, expressed in previous case law, namely that the decision to issue an EAW, when it is taken by an authority that participates in the administration of justice without being a court, must be capable of being the subject of judicial proceedings that meet the requirements of effective judicial protection. As a result, the Court ruled that the described procedure satisfies such

\footnotetext{
${ }^{17}$ It is worth noting that, according to the Lithuanian constitution and the case law of the Lithuanian constitutional court, the prosecutor general of Lithuania is not responsible for the administration of justice, and does not perform any functions related to the administration of justice during any pre-trial criminal investigation for which he is responsible. Apparently then, the Court decided to interpret the requirement of administering criminal justice autonomously, in a direct conflict with the national law. 18 Judgment of 9 October 2019.
} 
requirements and the Austrian authorities fall within the concept in question.

In the joined cases $\mathrm{C}-566 / 19$ and $\mathrm{C}-626 / 19,{ }^{19}$ the Court addressed the status of public prosecutors in France (called magistrates). The Court first dealt with the requirement of independence, stating that it is not called into question by the fact that French prosecutors are placed under the direction and supervision of their superiors, and are therefore required to comply with their instructions, nor by the fact they may be issued general criminal policy instructions by the Minister for Justice. The Court then discussed the requirement of effective judicial protection. It acknowledged that effective judicial protection may be achieved by various means, and a separate right of appeal against a decision to issue an EAW, as identified in one of the previous judgments, is only one possibility. In the case of the French legal system, judicial protection and the proportionality of an EAW is safeguarded by the fact that national arrest warrants, which may subsequently form the basis of EAWs, are issued by investigative judges, i.e. judicial authorities par excellence, whose decisions are subject to judicial review. Analogical argumentation and conclusions were presented in case C-625/1920 pertaining to Swedish prosecutors' offices.

The last case in the series, C-627/19, ${ }^{21}$ addressed a question concerning an EAW issued by a Belgian prosecutor's office, not for the purpose of a criminal prosecution, but for the purpose of enforcing a custodial penalty imposed by a final sentence. Belgian law does not provide for an appeal against a decision on issuing an EAW. However, the Court ruled that whenever an EAW

(...) is aimed at the enforcement of a penalty, judicial oversight is achieved by the enforceable judgment on which the arrest warrant is based. The enforcing judicial authority may presume that the decision to issue such an arrest warrant was taken in judicial proceedings in which the person sought was the beneficiary of guarantees as regards the protection of his fundamental rights. Furthermore, the proportionality of that arrest warrant also follows from the sentence imposed (...).

\footnotetext{
19 Judgment of 12 December 2019.

${ }^{20}$ Judgment of 12 December 2019.

${ }^{21}$ Judgment of 12 December 2019.
} 
As we see, the third series of judgments concerning the concept in question provided further requirements, as well as modifying the previous ones. Contrary to some earlier decisions, public prosecutors' offices in several Member States were classified as satisfying the requirements established by the Court, based not necessarily on their institutional position, but rather on different safeguard procedures that they provide.

\section{Semantic analysis}

It follows from the foregoing discussion that the concept of judicial authority is complex and problematic. The Court has not even attempted to determine its scope and meaning through a single, all-inclusive definition. Instead, it has identified various requirements that must be satisfied by a person or an institutional body in order to be considered a judicial authority. It should be apparent now, however, that these requirements do not form a list of necessary and sufficient conditions, as expected in the classical theory of categorisation. Rather, the Court's case law became an arena of an ongoing development and modification of these requirement. In one case the Court stated that public prosecutors' offices may not be counted as judicial authorities if they are instructed by the executive, such as a minister for justice. In another case it concluded that such instructions from a minister for justice are acceptable if the decision can be reviewed by a court. In yet another case it stated that such a review is not necessary in the case of issuing an EAW for the purposes of executing a sentence (as opposed to conducting criminal proceedings). Further distinctions and restrictions are likely to come with future cases, as the discussion about the concept of judicial authority can hardly be considered settled. What we are witnessing is a process of constant refinement of the concept in question.

In the analysed judgments, no less than seven requirements for a judicial authority may be distinguished (see: diagram 1$):{ }^{22}$

\footnotetext{
${ }^{22}$ Because of the theoretical, rather than practical, goals of the article, the list does not purport to be exhaustive. For instance, it does not take into account several important judgments concerning the sister concept of judicial decision that are undoubtedly relevant to the issue discussed here.
} 
1. being a member of the judiciary;

2. participating in administering justice;

3. authorisation of the decision by a court or a judge;

4. providing effective judicial protection of rights during criminal proceedings;

5. possibility of subjecting the decision to judicial review;

6. not being a member of the executive;

7. not being exposed to the risk of being subject, directly or indirectly, to directions or instructions in a specific case from the executive.

Diagram 1. The definitional aspect of the category JUDICIAL AUTHORITY:

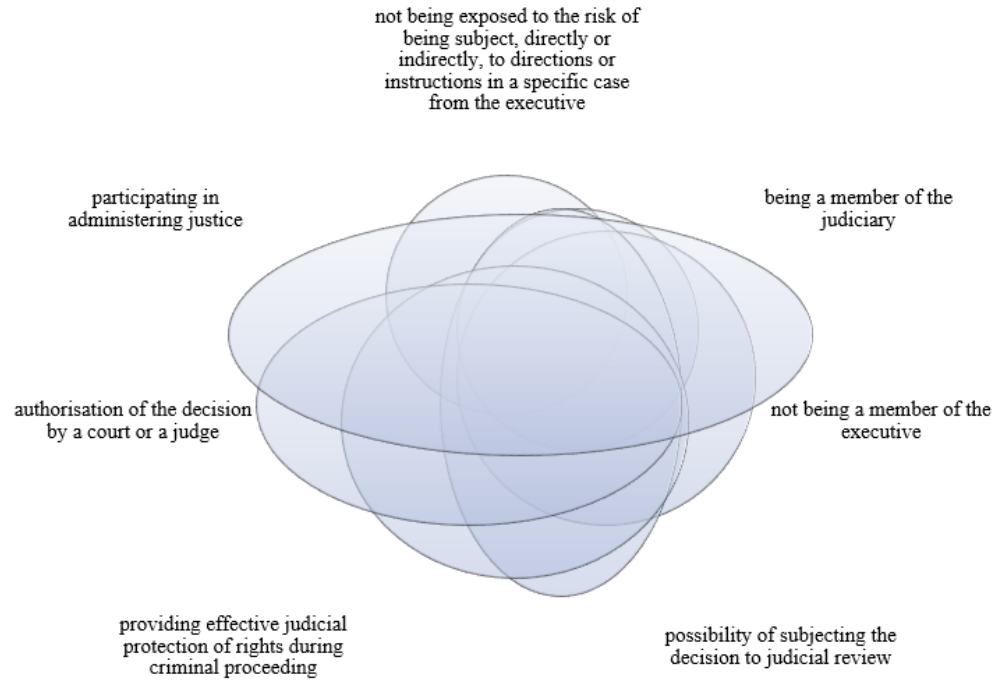

In terms of the theory of categorisation, these requirements can be perceived as features or attributes associated with the category JUDICIAL AUTHORITY. The important thing to note is that a person or an institutional body does not need to exhibit all these features in order to be classified as a judicial authority. We have seen that, according to CJEU case law, not all judicial authorities are members of the judiciary (i.e. the prosecutor general in Lithuania), not all are independent from the executive (i.e. the public prosecutors' offices in Austria), not all have their decisions subject to judicial review (i.e. 
public prosecutors in France and Sweden), not all provide effective judicial protection of rights during criminal proceedings (i.e. public prosecutors in Belgium in the case of issuing an EAW for the purpose of executing a custodial sentence), etc. In other words, the category JUDICIAL AUTHORITY reveals a prototypical structure. It explains why the Court has not opted for a rigid, classical definition. Instead, its case law provides an intricate network of requirements that take into account the institutional peculiarities of different national legal orders. It should also be noted that the list of requirements is not necessarily complete - it is very likely that future cases will cause the Court to identify additional requirements, or to refine those previously discerned, as has already occurred. This phenomenon has been duly recognised in legal translation theory: "word meaning is a dynamic entity subject to change in connection with the argumentative battle concerning meaning" (Engberg 2002: 385). It concurs with the idea that meaning is constructed in application to particular facts, and not in advance of application, which is advocated not only in cognitive linguistics, but also in hermeneutic tradition (Walshaw 2013).

The aforementioned discussion concerned the definitional or intensional dimension of the concept in question. In that aspect, the category JUDICIAL AUTHORITY, as construed by the CJEU, conforms to the tenets of prototype theory, namely to the lack of a rigid definition and to family resemblance as a principle governing its internal structure (Geerearts 1989: 7-8). Now let us turn to the referential or extensional dimension of the category JUDICIAL AUTHORITY.

As has already been mentioned, the types of institutional bodies or individuals notified by the Member States as judicial authorities are diverse (see: diagram 2). ${ }^{23}$ Those bodies that exhibit all the aforementioned features form the "core" of the category. They are the prototypical examples of judicial authorities, most notably various types of national courts (the white boxes on the diagram 2). Then, there are those that exhibit only a minimal number of relevant features, and thus cannot be classified as judicial authorities. For instance, Swedish police services do participate in conducting criminal proceedings and enjoy much institutional independency, but they lack other features, such as being a part of the judiciary, or providing an effective protection

\footnotetext{
${ }^{23}$ It should be noted, however, that this diversity has recently been diminishing due to the impact of CJEU case law.
} 
of rights (the grey boxes on the diagram 2). Finally, there are those that exhibit some of the features of the category. They are non-prototypical examples of judicial authorities and they form the "periphery". This is the case of public prosecutors' offices and prosecutors general (the white-grey boxes on the diagram 2). It should also be noted that the borderline of the category is blurred. Consequently, public prosecutors' offices and prosecutors general in some member states fall within the scope of the concept in question, while in others they do not. It depends on the number and the relative weight of the features they exhibit. As the recent CJEU case law illustrates, there are no hard and fast rules governing the process of their classification. The number of relevant features is potentially infinite, because there are infinite possibilities of how a national system of criminal justice can be constructed. Because of that, the fuzzy borderline of the concept in question should be considered rather a virtue than a drawback, just as Wittgenstein claimed (Wittgenstein 1953: 33).

Again, we can see that the treatment of the category JUDICIAL AUTHORITY by the CJEU conforms to fundamental characteristics of prototype theory. Firstly, there are certainly better (i.e. courts) and worse (i.e. prosecutors' offices) examples of the category. Secondly, the category has proved to be flexible and lacking rigid borders. This observation may seem to be conflicting with the nature of adjudication, as the Court has to decide every case in an all-or-nothing manner. In other words, each particular institution or person must be declared either as falling within the scope of the concept of judicial authority or not, tertium non datur. However, we have seen that, even within a given subcategory (i.e. a public prosecutor's office) the classifications made by the CJEU are neither homogeneous nor fully predictable. ${ }^{24}$

\footnotetext{
${ }^{24}$ This thesis is additionally supported by the discrepancies between Court judgments and the opinions of Advocates General on the subject matter. For the sake of brevity, however, this thread had to be omitted.
} 
Diagram 2. The referential aspect of the category JUDICIAL AUTHORITY. The colours of the boxes symbolise different levels of category membership. The lines between the boxes symbolise relative similarity (solid line - strong similarity, dotted line - weak similarity):

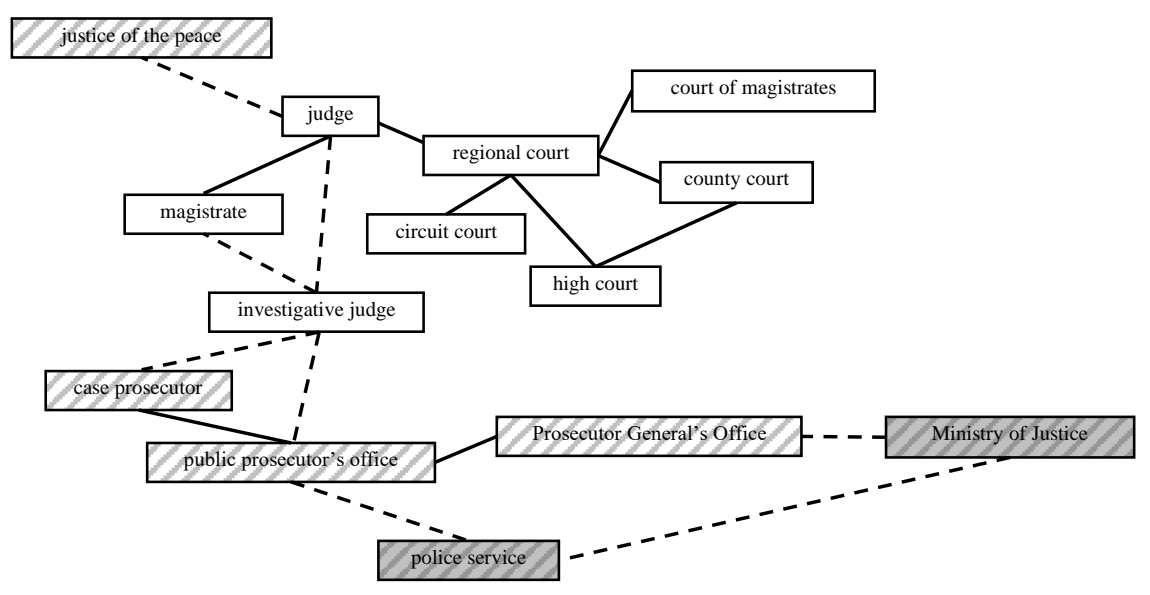

\section{Conclusions}

The common view about language and meaning shared by generations of lawyers and jurists is based on the classical theory of categorisation. This includes reliance on classical definitions, deductive reasoning and other tools of formal logic (Winter 2001: 6-12). However, in practice, legal rules do not always work as expected by this approach. As O.W. Holmes famously wrote: "The life of the law has not been logic: it has been experience" (Holmes 1882: 1). One of the reasons for this is that reality does not have a rigid, logical structure. As put by $\mathrm{H}$. Hart:

\footnotetext{
"If the world in which we live were characterised only by a finite number of features, and these together with all the modes in which they could combine were known to us, the provision could be made in advance for every possibility" (Hart 1961: 128).
}

But it cannot. Reality is much too complicated, manifold and unpredictable to be fully covered by any system of language or logic. Consequently, it is the prototype theory of categorisation that provides 
a more suitable description of the practice of interpreting and applying the law. As such, it offers a useful tool for legal theory.

The above statement has a universal appeal, as proved by numerous previous legal analyses employing the prototype theory to various theoretical as well as practical issues (see for example:Winter 2001; Hamilton 2002; Paul 2002; Solan 2010; Osenga 2011; Smith 2011). However, there are reasons to claim that the prototype theory may be particularly useful in the context of EU law. It turns out that the characteristics of EU law, namely multilingualism and conceptual autonomy, provide a very convenient opportunity to examine the mechanisms of human categorisation. These two features taken together serve to underline the difference between words and concepts or, accordingly, between the linguistic and conceptual levels of law. Whereas in a unilingual environment it is rather unnatural to detach a concept from the term naming it, in a multilingual environment - such as EU - it becomes not only a theoretical, but also a practical necessity. As a result, conceptual phenomena become more visible and susceptible to analysis.

This article has been deliberately restricted to the concept of judicial authority. However, further to my research of CJEU case law, many similar analyses could be provided to support this claim. For practical reasons, two types of concepts that seem to be particularly apt for this form of examination may be discerned. The first type is concepts denoted by highly technical, legal terms, such as judicial authority, detention, ${ }^{25}$ or probation measure. ${ }^{26}$ Their meaning is constructed against the background of national legal systems, which may vary significantly. As a result, they have to be construed to be flexible enough to embrace various institutional realities and to secure the purposes of the legal instruments they designate. The second type is concepts denoted by common language names for the purposes of tax classifications, such as beer, ${ }^{27}$ dry pasta ${ }^{28}$ packing containers, ${ }^{29}$ electrical machine with translation or dictionary functions, ${ }^{30}$

\footnotetext{
${ }^{25}$ See: judgments of 28 July 2016 C-294/16 PPU and of 14 May 2020 C-924/19 PPU and C-925/19 PPU.

${ }^{26}$ See: judgment of 26 March 2020 in Case C-2/19.

${ }^{27}$ See: judgment of 13 March 2019 in Case C-195/18.

${ }^{28}$ See: judgment of 6 September 2018 in Case C-471/17.

${ }^{29}$ See: judgment of 20 November 2014 in Case C-40/14.

${ }^{30}$ See: judgment of 11 June 2015 in Case C-58/14.
} 
thermometer, ${ }^{31}$ etc. There are obvious prototypical examples of such categories, and it is easy enough to formulate their approximate definitions. However, human technological and economical invention keeps throwing up novel, unpredictable examples that constantly challenge such definitions and reveal new layers of doubts. ${ }^{32}$ The Court appears to be fully aware of that. In such cases, it tends to refrain from formulating classical definitions of the concept in question, and instead rely on identifying requirements that are flexible and adjustable.

As has already been mentioned, the CJEU is often associated with a teleological (i.e. purposive) approach to legal interpretation, as opposed to a linguistic (i.e. textual) approach. The case study concerning the term judicial authority would be a good example of this approach. The requirements and exceptions identified by the Court for judicial authorities can hardly be derived from the dictionary meaning of the term. They are clearly effects of extralinguistic, teleological considerations. Note, however, that this is perfectly in line with cognitive linguistics and its denial of a separate level of purely linguistic meaning. If we adopt the encyclopaedic concept of meaning then we will no longer see the Court's approach as a rejection of linguistic methods of interpretation. Rather, we will expect the meaning of legal terms to be modified by a "dynamic matrix" of extralinguistic knowledge (Bajčić 2017: 166) and we will understand that it is shaped by the normative context of European and national legal orders (Šarčević 2000: 5). Although this is mainly a matter of perspective, I believe that prototype theory gives a more credible, more cohesive and more comprehensive account of the application of law, especially though not exclusively, by the Court of Justice of the European Union.

One final remark has to be made with a view to the practical consequences of the approach advocated in this article. After all, prototype theory is a linguistic - not a legal - theory. It reveals the mechanisms of conceptual categorisation. It may, as a result, lead jurists to adopt a different view about categorical borders (see: Bajčić 2017: 166). However, as mentioned earlier, it offers no excuse for a judge whose job is precisely to decide "whether a particular event in the world fits a legally relevant category" (Solan 2018: 338). Therefore, it should

\footnotetext{
${ }^{31}$ See: judgment 26 November 2015 in Case C-44/15.

${ }^{32}$ For instance: are noodles that were pre-cooked, fried and then packed in a dry state to be classified as dry pasta? Are paper, one-use indicators of a certain threshold temperature to be classified as thermometers?
} 
not be treated as a theory of how judges (or jurists, or lawyers) are supposed to interpret the law. Nor should it be used as a direct justification of any particular interpretive choice. Lawrence Solan, who is an undisputed champion of contemporary legal-linguistics, has noted: "[m)any of the problems concerning the construal of legal language are linguistic in nature. However, the solutions to these difficulties are not linguistic unless the legal system makes them so" (Solan 2018: 338). As rightly acknowledged by another scholar, "standards for the determination of legal meaning are necessarily internal to legal practice" (Fallon 2015: 1243). In other words, linguistic theories have the potential to enlighten those engaged in legal practice and help them properly understand the fabric of the language they happen to be working with. As a result, they may support certain approaches to legal interpretation and undermine others that are based on incorrect assumptions about language. At the same time, however, they cannot replace the legal considerations, legal values and legal arguments necessary to resolve interpretive questions in applying law.

\section{Bibliography}

Bajčić, Martina. 2017. New Insights into the Semantics of Legal Concepts and the Legal Dictionary. Amsterdam-Philadelphia: John Benjamin's Publishing.

Engberg, Jan. 2002. Legal Meaning Assumptions - What Are the Consequences for Legal Interpretation and Legal Translation. International Journal for the Semiotics of Law 15 (4): 378-388.

Fallon, Richard H. 2015. The Meaning of Legal "Meaning" and Its Implications for Theories of Legal Interpretation. University of Chicago Law Review 82 (3): 1235-1308. Available at: https://chicagounbound.uchicago.edu/uclrev/vol82/iss3/3 (accessed on 15 September 2020).

Fennelly, Nial. 1996. Legal Interpretation at the European Court of Justice. Fordham International Law Journal 20 (3): 656-679. Available at: https://ir.lawnet.fordham.edu/cgi/viewcontent.cgi?article $=152$ $6 \&$ context=ilj (accessed on 15 September 2020). 
Fillmore, Charles J. 1975. An Alternative to Checklist Theories of Meaning. Proceedings of the First Annual Meeting of the Berkeley Linguistics Society. https ://doi.org/10.3765/bls.v1i0.2315 (accessed on 15 September 2020).

Geerearts, Dirk. 2016 (1989). Prospects and Problems of Prototype Theory. Diachronia 4, A53: 1-16.

Hamilton, Jonnette. 2002. Theories of Categorization: A Case Study of Cheques. Canadian Journal of Law and Society 17 (1): 115 138.

Hart, Herbert L.A. 1994 (1961). The Concept of Law. Oxford: Oxford University Press.

Holmes, Oliver W. Jr. 1882. The Common Law (1 ${ }^{\text {st }}$ ed.). London: Macmillan. Retrieved 15 July 2020 via Project Gutenberg: https://www.gutenberg.org/files/2449/2449-h/2449-h.htm (accessed on 15 September 2020).

Klimek, Libor. 2015. European Arrest Warrant. Cham-HeidelbergNew York-Dordrecht-London: Springer.

Kutscher, Hans. 1976. Methods of Interpretation as Seen by a Judge at the Court of Justice. Judicial and Academic Conference, 27-28 September 1976, Luxembourg: Office for Official Publications of the European Communities, 5-51.

Lakoff, George. 1973. Hedges: A Study in Meaning Criteria and the Logic of Fuzzy Concepts. Journal of Philosophical Logic 2 (4): 458-508.

Lakoff, George. 1987. Women, Fire, and Dangerous Things: What Categories Reveal About the Mind. Chicago: University of Chicago Press.

Langacker, Ronald W. 2008. Cognitive Grammar. A Basic Introduction. Oxford: Oxford University Press.

Lenaerts, Koen, and José A. Gutirrez-Fons. 2013. To Say What the Law of the EU is: Methods of Interpretation and the European Court of Justice. EUI Working Paper AEL 2013. Available at: https://cadmus.eui.eu/handle/1814/28339 (accessed on 15 September 2020).

Łachacz, Olga, and Rafał Mańko. 2013. Multilingualism at the Court of Justice of the European Union: Theoretical and Practical Aspects. Studies in Logic, Grammar and Rhetoric, vol. 34 (47): 75-92. 
Mellinkoff, David. 2004 (1963). The Language of the Law. Eugene, Oregon: Wipf and Stock Publishers.

Osenga, Kristen. 2011. A Penguin's Defence of the Doctrine of Equivalents: Applying Cognitive Linguistics to Patent Law. New York University Journal of Law \& Liberty 6: 313-358.

Pacho Aljanti, Lucie. 2018. Multilingual EU Law: a New Way of Thinking. European Journal of Legal Studies, vol. 10: 5-46. http://hdl.handle.net/1814/59865 (accessed on 15 September 2020).

Paluszek, Karolina. 2019. Komparatystyka językowa jako narzędzie interpretacyjne Trybunatu Sprawiedliwości Unii Europejskiej. Warszawa: Diffin.

Paul, Jeremy. 2002. Changing the Subject: Cognitive Theory and the Teaching of Law. Brooklyn Law Review 67 (4): 987-1022.

Questionnaire on the CJEU's judgments in relation to the independence of issuing judicial authorities and effective judicial protection (by Eurojust \& European Judicial Agency). Available at: http://www.eurojust.europa.eu/doclibrary/Eurojust-

framework/Pages/casework.aspx (accessed on 15 September 2020).

Rosch, Eleanor. 1973. On the Internal Structure of Perceptual and Semantic Categories. In Cognitive Development and the Acquisition of Language, ed. T. Moore, 111-144. New York: Academic Press.

Rosch, Eleanor. 1975. Cognitive Representations of Semantic Categories. Journal of Experimental Psychology: General 104 (3): 192-233. Available at: https ://doi.org/10.1037/00963445.104.3.192 (accessed on 15 September 2020).

Rosch, Eleanor. 1978. Principles of Categorization. In Cognition and Categorization, eds. Eleanor Rosch and Barbara Lloyd, 27-48. Hillsdale, NJ: Lawrence Erlbaum.

Rosch, Eleanor. 2011. "Slow lettuce": Categories, Concepts, Fuzzy Sets, and Logical Deduction. In Concepts and Fuzzy Logic, eds. Radim Belohlavek and George J. Klir, 89-120. CambridgeOxford: The Massachusetts Institute of Technology Press.

Šarčević, Susan. 2000. Legal Translation and Translation Theory: a Receiver-oriented Approach. https://www.semanticscholar.org/paper/Legal-Translationand-Translation-Theory-\%3A-a- 
\%C5\%A0ar\%C4\%8Devi\%C4\%87/c266c61e8c8f3c89f519b47 3c1387c9703132d76 192 (accessed on 15 September 2020).

Šarčević, Susan. 2013. Multilingual Lawmaking and Legal (Un)Certainty in the European Union. International Journal of Law, Language and Discourse, vol. 3 (1): 1-29.

Smith, Michael R. 2011. Linguistic Hooks: Overcoming Adverse Cognitive Stock Structures in Statutory Interpretation. Legal Communication \& Rhetoric: JALWD 8 (1): 1-36.

Solan, Lawrence. 2010. The Language of Statutes. Laws and Their Interpretation. Chicago \& London: The University of Chicago Press.

Solan, Lawrence. 2018. The Interpretation of Legal Language. Annual Review of Linguistics vol. 4: 337-355.

Taylor, John R. 2003 (1989). Linguistic Categorization. Oxford: Oxford University Press.

van der Mei, Anne Pieter. 2017. The European Arrest Warrant System: Recent Developments in the Case Law of the Court of Justice. Maastricht Journal of European and Comparative Law 2017, vol. 24 (6): 889-904.

Walshaw, Christopher. 2013. Interpretation is Understanding and Application: The Case for Concurrent Legal Interpretation. Statute Law Review vol. 34: 101-127.

Winter, Steven L. 2001. A Clearing in the Forest. Law, Live and Mind. Chicago: The University of Chicago Press.

Wittgenstein, Ludwig. 1953. Philosophical Investigations. Oxford: Basil-Blackwell. 